\title{
Memorias americoafricanas en el trabajo de artistas brasileñas contemporáneas*
}

\section{Maria Emilia Sardelich* \\ Marian López Fernandez Cao**}

La memoria hace referencia a un conjunto de funciones psíquicas que permiten la actualización de imágenes de hechos pasados o que se representan como pasados. A diferencia de los estudios históricos, los de la memoria resaltan las subjetividades, amplían la discusión más allá del recuerdo y el olvido, y desplazan el debate hacia quien tiene el derecho a narrar su historia y aquellos que en ella se encuentran. Las inquietudes en torno a la memoria y sus lugares también se hacen visibles en el inquieto horizonte artístico, en el que pasados recientes y distantes se articulan en registros sobre diversas formas de traumas. Este artículo propone una reflexión sobre las relaciones entre arte y memoria a partir de la producción de dos artistas brasileñas contemporáneas: Rosana Paulino (São Paulo, 1968) y Aline Motta (Niterói, 1974). El análisis de esa producción se fundamenta en la interdisciplinaridad de los estudios de la memoria y destaca cómo la creación artística ofrece una posibilidad de resignificación individual y colectiva. Asimismo, conceptúa memorias americoafricanas como aquellas que emergen no solo en la memoria individual de las artistas presentadas en este artículo, sino también en la de muchas otras mujeres que se identifican con Americoáfrica como un sistema etnogeográfico de referencia. Son memorias americoafricanas porque se han gestado en la resistencia y creatividad contra la opresión, la humillación y la deshumanización, y que se insurgen contra la historia única proponiendo una revisión de la historiografía del país y del arte producido a partir de esos lugares.

Palabras clave: memoria, archivo, arte contemporáneo, americoafricanidad Rosana Paulino, Aline Motta.

\begin{abstract}
doi 10.11144/javeriana.mavae16-1.maee Fecha de recepción: 19 de junio de 2020 Fecha de aceptación: 19 de agosto de 2020 Disponible en línea: 1 de enero de 2021
\end{abstract}

* Artículo de reflexión, resultado del proyecto de investigación posdoctoral "Artes visuales y feminismos: interconexiones entre crítica, historia del arte y formación", realizado en la Universidad Complutense de Madrid, 2019-2020.

** Licenciada en Música por la Universidade Católica do Salvador y en doctora en Educación por la Universidade Federal da Bahía, con investigación posdoctoral por la Universidad Complutense de Madrid. Profesora de la Universidade Federal da Paraíba. ORCID: 0000-0001-8134-8807. Correo electrónico: sardelich@ce.ufpb.br

*** Licenciada en Bellas Artes por la Universidad Complutense de Madrid y doctora en Bellas Artes por la Universidad Complutense de Madrid. Profesora de la Universidad Complutense de Madrid.

ORCID: 0000-0003-0421-3612.

Correo electrónico: mariaan|@ucm.es

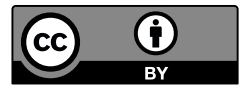




\section{American-African Memories in the Work of Contemporary Brazilian Artists}

Memory refers to a set of psychic functions that allow the updating of images of past events or events that are represented as past. Unlike historical studies, memory studies highlight subjectivities, expand the discussion beyond memory and oblivion, and shift the debate towards who has the right to narrate their history and those who are in it. The concerns about memory and its places also become visible in the restless artistic horizon, in which recent and distant pasts are articulated in registers about various forms of trauma. This paper proposes a reflection on the relationship between art and memory based on the production of two contemporary Brazilian artists: Rosana Paulino (São Paulo, 1968) and Aline Motta (Niterói, 1974). The analysis of this production is based on the interdisciplinary nature of memory studies and highlights how artistic creation offers a possibility of individual and collective resignification. Likewise, it conceptualizes African-American memories as those that emerge not only in the individual memory of the artists presented in this article, but also in that of many other women who identify with Africa-America, as a reference ethnogeographic system. They are African-American memories because they have been born in resistance and creativity against oppression, humiliation and dehumanization, and because they insurrect against the unique history, proposing a review of the historiography of the country and the art produced out of those places.

Keywords: memory, archive, contemporary art, African-America, Rosana Paulino, Aline Motta.

\section{Memórias americo-africanas na obra de artistas brasileiras contemporâneas}

A memória refere-se a um conjunto de funções psíquicas que permitem a atualização de imagens de fatos passados ou que são representados como passados. Diferentemente dos estudos históricos, os estudos da memória destacam as subjetividades, ampliam a discussão além da lembrança e do esquecimento e movem o debate para quem tem o direito de contar sua história e para aqueles que nela estão. As perguntas sobre a memória e seus lugares também são visíveis no inquieto horizonte artístico, em que passados recentes e distantes se articulam em registros sobre diversas formas de traumas. Este artigo propõe uma reflexão sobre as relações entre arte e memória a partir da produção de duas artistas contemporâneas brasileiras: Rosana Paulino (São Paulo, 1968) e Aline Motta (Niterói, 1974). A análise dessa produção se baseia na interdisciplinaridade dos estudos da memória e destaca como a criação artística oferece uma possibilidade de ressignificação individual e coletiva. Da mesma forma, conceitua memórias afro-americanas como aquelas que emergem não apenas na memória individual das artistas apresentadas neste artigo, mas também na de muitas outras mulheres que se identificam com a Afro-América, como um sistema etnogeográfico de referência. São memórias afro-americanas porque se gestaram na resistência e na criatividade contra a opressão, a humilhação e a desumanização, e que se levantam contra a história única, propondo uma revisão da historiografia do país e da arte produzida a partir desses lugares.

Palavras-chave: memória, arquivo, arte contemporânea, américo-africanidade, Rosana Paulino, Aline Motta. 
La noche no adormece en los ojos de las mujeres, hay más ojos que sueños donde lágrimas aplazadas velan el tiempo de nuestros húmedos recuerdos.

Conceição Evaristo Introducción

$>$ La memoria como facultad para retener, repetir y evocar acontecimientos hace referencia a un conjunto de funciones psíquicas que permiten la actualización de imágenes sobre hechos pasados o que se representan como pasados. Según eso, los estudios de la memoria engloban distintas áreas del conocimiento, como la biología, la educación, la neurología, la psicología, el psicoanálisis, la sociología, entre otras, volcadas tanto para las cuestiones individuales como sociales.

Desde los inicios del siglo XX, el sociólogo Maurice Halbwachs (1877-1945) hizo énfasis en las relaciones de la memoria individual con las estructuras sociales y señaló la memoria colectiva como una corriente de pensamiento continuo, capaz de vivir en la conciencia del grupo que la sostiene (Halbwachs 1990). Para Le Goff (1990), los fenómenos de la memoria, en sus aspectos biológicos o psicológicos, se refieren a los sistemas dinámicos de estructuración y autoorganización individual o grupal, que se mantienen en la medida en que esa organización los reconstituye. Esos sistemas son alimentados por los lenguajes. El autor señala que el desarrollo de la cibernética y la biogenética, a mediados del siglo XX, ampliaron la noción de memoria y la expandieron a los ordenadores y al código genético como una memoria hereditaria. Aunque la designación de memoria se haya extendido a la cibernética, Todorov (2000) considera inadecuado llamar memoria al dispositivo de los ordenadores para conservar información, puesto que este no realizaría la operación constitutiva de la memoria que es la selección. Si en el inicio del siglo XX los regímenes totalitarios se ensañaron para controlar y eliminar vestigios del pasado, en las postrimerías del milenio las amenazas a la memoria se producían no por la supresión, sino por la sobreabundancia, por un desenfrenado consumo y descarte de informaciones. Todorov (2000) recalca que, en un mundo alejado de las tradiciones, entorpecido y seducido por las exigencias de la sociedad del ocio, la humanidad estaría condenada a celebrar el olvido.

La noción de lugares de memoria se consolida al mismo tiempo que la dimensión ritual de la vida se debilita. Nora (1993) considera que el concepto de lugares de memoria nace y vive del sentimiento de que no hay memoria espontánea, sino que es necesario crear archivos, mantener aniversarios, organizar 
celebraciones, porque esas acciones no son naturales. Esa sería la razón por la que las minorías defienden con ahínco el derecho a sus memorias para mantener viva la verdad de los distintos grupos sociales, puesto que una "historia única" (Adichie 2019) rápidamente barrería los vestigios de esos lugares. Es una memoria archivística que se apoya sobre lo que hay de más concreto en el registro, lo más visible en la imagen. Ninguna época anterior fue tan voluntariamente productora de archivo como en la que estamos. El sentimiento de un acelerado y definitivo desaparecimiento, combinado con la idea de un presente verdadero y futuro incierto, confiere al más modesto de los vestigios la dignidad virtual de memorable. Es una memoria registradora que delega en el archivo la ocupación de recordar. La obsesión por el archivo afecta al mismo tiempo la preservación integral del presente y del pasado, por el acumulo de vestigios, imágenes, discursos, signos visibles de lo sucedido. Producir archivo es el imperativo de nuestra época.

Un ineludible sentimiento archivador también se hace visible en el inquieto horizonte artístico contemporáneo, en el cual pasados recientes y distantes se articulan en registros sobre diversas formas de violencia, atentados, diásporas, éxodos, epistemicidios, feminicidios, fronteras, genocidios, guerras, memoricidios, migraciones y tráfico humano. Arfuch (2014) clasifica como trabajos del arte de la memoria aquella producción artística que se aleja de la presentación de pruebas y testigos. En los trabajos del arte de la memoria, el yo fluctúa entre formas autoficcionales con intervención de la historia de la vida privada o sin ella. Esa producción artística está marcada por el envolvimiento personal en lo que se cuenta, el impacto emocional que eso supone, la vida como narración, la inquietud con el pasado, la búsqueda de huellas, la necesidad de recurrir a otros para elaborar la propia historia. Son trabajos que ponen en juego un pasado colectivo y traumático, no ya simplemente para recordar, ejercitando una facultad de la mente y la afectividad, "sino más bien indagar, multiplicar las preguntas, aceptar la tensión irresuelta, quizá, para siempre un diferendo" (Arfuch 2000, 37).

Este artículo propone una reflexión sobre las relaciones entre arte y memoria a partir de la producción de dos artistas brasileñas contemporáneas: Rosana Paulino (São Paulo, 1968) y Aline Motta (Niterói, 1974). El análisis de esa producción se fundamenta en la interdisciplinaridad de los estudios de la memoria y destaca cómo la creación artística ofrece una posibilidad de resignificación individual y colectiva, de reconstitución y reconstrucción de sí en gestos leídos, escuchados, contemplados, interpretados por otros. Destaca las relaciones entre la expresión artística y las prácticas de archivo en la intersección memoria y referenciación histórica. Para alcanzar esos objetivos, el artículo se organiza del siguiente modo. Inicialmente los fundamentos teóricos que sostienen la interpretación de la producción artística. A continuación, el contexto de esa producción artística que presenta un breve panorama de la sociedad brasileña del siglo XX, el mito de democracia racial y algunas de las voces que lo contestan, como la voz de la antropóloga y activista feminista Lélia Gonzalez (1935-1994). Las disputas en torno a una historia única de Brasil, todavía inmerso en la colonialidad, abren el camino para el concepto de memorias americoafricanas. Presenta las obras Parede da memória y Assentamento, de Rosana Paulino; Escravos de Jó e Filha Natural, de Aline Motta. Y finalmente las conclusiones.

\section{Estudios de la memoria, arte y archivo}

La preocupación por la memoria marcó un giro en el campo de los estudios culturales alrededor de la década de los ochenta y configuró los estudios de la memoria. Un giro indica un cambio físico de posición, de sentidos, de orientación cognitiva. A diferencia de los estudios históricos, los de la memoria resaltan las subjetividades y el momento en que la experiencia vivida se transforma en historia. Como consecuencia, las discusiones sobre la memoria se 
ampliaron más allá del recuerdo y olvido, se expandieron a la argumentación sobre quién tiene derecho a narrar la historia y cuáles son los grupos que en ella se encuentran. Esas cuestiones tratan de relaciones de poder y representación que afectan a todas las personas, por inclusión o por exclusión a ese derecho. Las personas incluidas no solo narran su historia, sino que también eligen qué, cómo, dónde y por qué cuentan. Las personas excluidas colman los silencios con relatos orales, saturan los apagamientos en tejidos bordados, en sombreros adornados, aunque no ocupen los legitimados espacios de poder autorizados por las personas incluidas.

Dada la naturaleza selectiva de la memoria como relato inacabado y moviente, esta también se enfrenta a las diversas formas de narrar. El arte, en todas sus manifestaciones, sería, para Arfuch (2014), un espacio privilegiado para el despliegue de la memoria y las narrativas en pugna, que confrontan contenidos y concepciones en torno a la representación del relato que supone su puesta en escena. De eso deduce los inúmeros riesgos en torno a las formas, la cristalización y la estetización de la memoria.

A partir de un enfoque psicoanalítico, Nicholson (2018) indica que los sucesos percibidos como amenaza a la integridad física propia o ajena producen miedo intenso, impotencia u horror. Señala que los griegos usaron la palabra trauma para referirse a la forma en que el cuerpo podría ser perforado, atravesado, y la palabra traumático como herida o perforación. El psicoanálisis aplicó esa idea a la mente que altamente selectiva filtra los estímulos externos para mantener un equilibrio interno posible y atribuye un lugar central a la memoria. Los conflictos intrapsíquicos sobrevienen de esa relación con el pasado, de la represión de hechos y sucesos que le resultan inaceptables. En tanto sean reprimidos, los recuerdos permanecen activos y obstaculizan la vida. Las heridas psicológicas ocultas permanecen expuestas mucho tiempo después de que se curen las heridas físicas, cuando las personas traumatizadas tienen que seguir viviendo y lo intentan valientemente. Los fantasmas que acechan a las personas traumatizadas son los ecos reales de eventos abrumadores sin resolver que, por medio del proceso creativo, pueden transformarse en una experiencia nueva, relevante y significativa.

Los/las artistas vienen dando muestras de la elaboración de traumas individuales y colectivos hace siglos. Cao (2018) afirma que, si la aguja punzante del trauma tiene la capacidad de esconderse en nuestro cuerpo, la creación, que nos liga al terreno del juego, del cuidado, de la imaginación como espacio emancipador, puede movilizar la capacidad de dar sentido y estructurar lo interno, la capacidad de narrarnos de nuevo. De esa manera, la creación invita a un reinicio sin ruptura, por llevarnos a ver con otros ojos las vías ya existentes. El proceso creador señala y desmarca a la vez la huella de lo marcado, no lo encubre, sino que revierte la mirada "en nosotros/as mismos/as, como hacedores/as de relatos posibles, siempre inconclusos, siempre provisionales" (Cao 2018, 25). La creación activa miradas revertidas que permiten afrontar conflictos desde puntos de vista diversos, reinauguran la relación con el mundo y actualizan la relación con los otros. En la experiencia de la producción artística como lugar simbólico, se ensaya la vida, se permite probar el placer y el dolor de un modo seguro, olvidar las certezas, aventurar significados diversos, disfrutar "de la ambigüedad que produce el no saber a ciencia cierta qué estamos realizando, qué estamos observando" (29).

Si narrar es condición de estar en el mundo, por medio de la narración podemos comprender el mundo y comprendernos, a decirlo y decirnos con nuestras imágenes. Cao (2018) remarca que el trabajo del duelo a través del proceso creador conduce a una nueva realidad, transforma la experiencia física de pérdida y enfermedad en una forma nueva como medio de unificar la experiencia interna y externa. Es un proceso de reestructuración del yo en la experiencia plástica y el orden formal que ayuda al creador a superar la dolorosa separación o hecho traumático y hace que el tiempo se suspenda. Crear hace aparecer una forma desde una "experiencia que se ha hecho memoria emocional" (27). 
Una persona nunca recuerda eventos traumáticos aislada, sino en el contexto de su medio social. De la misma manera, hay una intensa relación entre memoria, creación y las imágenes tanto en el proceso individual como en el colectivo por la carga afectiva, la tensión entre presencia y ausencia, así como la potencialidad de las imágenes para iluminar zonas reprimidas de la experiencia personal que nunca deja de ser colectiva. Ruido (2018) considera que, así como sucede con la construcción del género, las imágenes, sean del ámbito artístico o mediático, son tecnologías de memoria poderosas que ayudan a elaborar y fijar nuestra memoria colectiva y son utilizadas por los aparatos ideológicos del Estado para construir la memoria hegemónica desde mucho antes del nacimiento de la disciplina histórica. Por consiguiente, los archivos son lugares de la memoria y los artistas utilizan imágenes de archivos organizados para construir una memoria hegemónica para crear otras versiones que no forman parte del relato oficial, por ejemplo, los traumas colectivos. De igual manera, los artistas construyen archivos como un trabajo de duelo, como un proceso de reestructuración personal y colectiva.

La producción artística contemporánea utiliza la metodología de la documentación para construir relatos verosímiles de historias personales en la encrucijada colectiva. Romero (2018) clasifica como archivos abiertos aquella producción artística que se sirve de los archivos como dispositivos para la reconstrucción de la memoria desde el presente, para la transformación del ahora desde los restos de un tiempo pasado a ser contado de nuevas formas. El autor señala que los archivos abiertos permiten la construcción de nuevas narraciones a partir de la desestabilización, que expresan algo "cuando no se puede o no se sabe cómo pronunciar para la construcción de miradas renovadas" (151). Los archivos abiertos van más allá del registro, la conservación y clasificación, pues generan choques con el presente, a partir de la iluminación de lo oculto, de la conexión entre lo que parece distante y la comprensión desde dentro.

\section{Querellas de la historia única de Brasil}

Desde el Renacimiento y más intensamente a partir del siglo XVIII se ha creado en Europa un tipo de sociedad que ha dejado de apreciar las tradiciones y el pasado para enaltecer el porvenir. Todorov (2000) afirma que esas sociedades han pasado de la heteronomía a la autonomía, de la legitimación que procede de la tradición para el modelo del contrato y su adhesión. El contrato, que se origina en el consentimiento y en la elección de la mayoría, nutre el modelo que regula las instituciones. Aunque las huellas de legitimación mediante la tradición no sean eliminadas, es lícito oponerse a la tradición en nombre de la voluntad general o del bienestar común. En consecuencia, la memoria es destronada en provecho de algunos principios universales y de la voluntad general. A partir del giro decolonial, que se posiciona por un pensamiento otro, esta sería una de las trampas en la que nos ha encerrado la modernidad/colonialidad que produjo, y sigue produciendo, en nombre de principios universales, privilegios para la blanquitud, ${ }^{2}$ al coste de destrucción ecológica, epistemicidios y genocidios de la alteridad.

En el "sistema mundo moderno/colonial" (Quijano 2005), la identidad racial es un instrumento de clasificación social de la población que con el tiempo se fue codificando en los rasgos fenotípicos de los colonizados como el color, asumidos como característica emblemática de la categoría racial. En ese sistema, las poblaciones africanas capturadas, esclavizadas ${ }^{3}$ y dispersas por el continente denominado América fueron las más explotadas, puesto que la economía dependía de la obligada fuerza de trabajo de sus cuerpos. Para Gómez (2015), América Latina es una construcción de la retórica libertadora de la modernidad asociada a la lógica de control de la colonialidad. La estética que se firma a partir del siglo XVIII es una de las claves para la construcción de un campo y una historia nacional del arte como parte de un relato de las naciones americanas que pretendían incluirse en la modernidad, no más a partir del espejo de 
España y Portugal, sino de Francia, Inglaterra y Alemania. El autor argumenta que, en principio, el proceso artístico no es, sino que se vuelve colonial como mediador de relaciones humanas de subordinación colonial, valiéndose de formas racializadas de representación del otro que reducen su ser, sentir, pensar, hacer. Así, esa estética andro- y eurocéntrica está presente en la construcción y transformación de la matriz colonial del poder, en el ser de indígenas, africanos y sus descendientes, tras lo cual se convierte en un poderoso instrumento para la clasificación y diferenciación de los seres humanos.

Brasil fue el último país del continente americano en revocar el régimen de la esclavitud a finales del siglo XIX, en 1888, momento en el que la población negra ya alcanzaba cerca del $50 \%$ (Theodoro 2008). A pesar del término oficial de la esclavitud y el cambio político al régimen republicano, un año después los señores blancos que condujeron el futuro de la nación brasileña no asalariaron a la población negra, sino que trataron de sustituirla por inmigrantes europeos y asiáticos. Esa inmigración masiva atendió al ideal de emblanquecimiento de la población, bajo los principios de la eugenesia, vista a finales del siglo XIX e inicios del siglo XX como condición necesaria para el avance del país, que proyectó su sociedad imaginada desde una perspectiva eurocéntrica, sin democratizar las relaciones sociales y políticas excluyendo a las poblaciones no blancas.

Gilberto Freyre (1900-1987), uno de los hijos y teóricos de la oligarquía brasileña de origen portugués, intentó explicar la formación de la identidad brasileña a partir del análisis de la sociedad colonial, anclado en la idea de mestizaje que para él sería el factor responsable de la reconciliación étnica en Brasil (Freyre 2003). La noción de democracia racial y pacifismo sigue hasta hoy manteniendo un imaginario de relaciones sociales armónicas y camuflando un Estado erigido sobre las desigualdades raciales. Un mito opera con antinomias que niegan, justifican la realidad negada por él y sustituye "la realidad por la representación imaginaria haciendo invisible la realidad existente" (Chauí 2013, 7). Una de las voces que no se calló frente a los mitos de la no violencia y reconciliación étnica brasileña ha sido la de Lélia Gonzalez.

Aunque los consentidos señores de la historia única de Brasil ensalzaran las calidades de bondad y ternura de las mujeres esclavizadas como amas de cría y su responsabilidad en el pacífico mestizaje de la sociedad brasileña, Lélia Gonzalez se posicionó en contra de esa "mirada que no ve la dimensión racial ni la histórica herencia de las mujeres latinoamericanas de las ideologías de clasificación racial y sexual" (Gonzalez 2011, 13). Acusó la falacia jurídica de la supuesta igualdad de todos ante la ley y remarcó que el sofisticado racismo latinoamericano mantiene las poblaciones indígenas y negras subordinadas gracias a la ideología del emblanquecimiento, al reproducir y perpetuar la creencia en las clasificaciones y los valores de la cultura occidental blanca como los verdaderos y universales. Puso de relieve la racialización de los espacios físicos y sociales, que fijó en las favelas, las barriadas y los campamentos de ocupas a las poblaciones negras. Son espacios que cuentan con la fuerza policial de intervención solo para "reprimir, violentar, amedrentar" (Gonzalez 1982, 15) y se extienden al sistema penitenciario.

Como mujer negra, reconoció el duro proceso de aprendizaje de esa identidad en una sociedad que oprime y discrimina tal condición. Relató cómo el mito de la superioridad blanca fragmentó su propia identidad étnica subrayando "el lavado cerebral hecho por el discurso pedagógico brasileño" (Gonzalez 1994, 385), pues, en la medida en que avanzaba en su escolarización, rechazaba su condición de mujer negra a fuerza de aprender las fantasías blancas sobre lo que debería ser la negritud: animal, primitiva, dedicada al trabajo pesado, intelectualmente incapaz, ladrona, irresponsable, lo que justificaría la persecución policial.

Es a partir de los fundamentos del psicoanálisis que Lélia González discute el racismo y el sexismo en la cultura brasileña que hace referencia a la conciencia y la memoria de mujeres y hombres negros (Gonzalez 1984). Entiende como conciencia el lugar de la alienación, el lugar de la imposibilidad de constituirse en sujeto de su propia historia, donde el discurso ideológico de 
la blanquitud se hace presente. De manera opuesta, la memoria sería el lugar de los grabados, de los registros, de los dibujos de sentimientos, de las tristezas y dolores, que restituyen una historia que todavía no ha sido escrita, el lugar donde emerge la verdad que se estructura como ficción. La memoria tiene sus astucias y habla por medio de las omisiones, equivocaciones y lapsus de la conciencia. Expuso esa forma más sutil y peligrosa del racismo, el de las representaciones en los "medios de comunicación de masas y aparatos ideológicos" (Gonzalez 1988b, 6), la estigmatización del cuerpo de mujeres y hombres negros como animales para la explotación laboral y sexual. Reiteró la persecución sobre los cuerpos negros, así como el propósito de su domesticación y aniquilamiento. Hizo sonar el ruidoso silencio sobre las contradicciones del mito de la democracia racial como "modo de representación/discurso que encubre la trágica realidad vivida por mujeres y hombres negros en Brasil" (Gonzalez 1979, 11).

Para Gonzalez el mestizaje del país se hizo por medio de la violencia sexual, por el estupro de las mujeres negras esclavizadas por el colonizador. Valoró la resistencia pasiva de esas mujeres que tuvieron que servir, también por fuerza, como ama de leche, nodriza de los otros hijos del estuprador. Remarcó la coercibilidad de ese contacto forzado, molesto y obligado (Gonzalez 1981), que evidenció el dolor y la humillación de la ama de leche, de brazos, de cría, que, en su resistencia pasiva, "hizo la cabeza"4 del dominador, y afracanizó la cultura del violador. Clasificó de "neurosis de la cultura brasileña" (Gonzalez 1984, 223) la identificación de la cultura nacional con los símbolos de matriz africana, pero que se cree blanca europea. Es a partir de ese contexto neurótico de profunda iniquidad que la antropóloga inscribió la categoría americoafricanidad, con la que reconocía a las mujeres americoafricanas y amerindias como las más oprimidas y explotadas del "capitalismo patriarcal racista dependiente" (Gonzalez 1988b, 71). Propuso la categoría americoafricanidad para confrontarla con la de afroamericano y africano-americano, y observó que estas indicarían que solo existiría población negra en los Estados Unidos, dado el imperialismo estadounidense sobre el continente americano. La categoría americoafricanidad considera las implicaciones políticas, culturales y democráticas, puesto que ultrapasa limitaciones territoriales, lingüísticas y ideológicas, así como abre perspectivas más allá del carácter geográfico para un entendimiento otro.

El concepto de americoafricanidad incorpora el proceso histórico de la intensa dinámica cultural de adaptación, resistencia, reinterpretación y creación de nuevas formas de existencia afrocentrada. El valor metodológico de esa categoría reside en el hecho de reanudar un proceso forjado en el interior de diferentes sociedades en una determinada parte del mundo. "Como sistema etnogeográfico de referencia, Americoáfrica es nuestra creación junto a nuestros ancestros en el continente donde vivimos, inspirados en modelos africanos" (Gonzalez 1988b, 77). Según esto, la experiencia americoafricana se distingue de la experiencia africana que permaneció en su propio continente, puesto que su diferencial es la "heroica resistencia y creatividad en la lucha contra la esclavización, el exterminio, la exploración, la opresión y la humillación" (Gonzalez 1988a, 78). La autora reconoce que la americoafricanidad ya se expresaba durante el régimen de la esclavización en prácticas de resistencia cultural y en el desarrollo de formas alternativas de organización social que se concretizó en los "quilombos, cimarrones, cumbes, palenques, marrinajes y marron societies" (Gonzalez 1988a, p. 79) dispersas por el continente americano.

Sobre el conflicto que se opera en el ámbito de las políticas oficiales de memorias en Brasil, Cunha (2017) advierte que aquello que el Estado pretende preservar y preserva no siempre representa la totalidad de las memorias nacionales, como en las memorias afrobrasileñas, que han sido manipuladas y deturpadas en función de la política de emblanquecimiento nacional aliado a un imaginario eurocéntrico. Observa que en un contexto social marcado por la dominación, exclusión y silencio para invalidar todo aquello que pudiera poner en riesgo la imagen de la comunidad idealizada, los museos de Brasil tienen clase, color y género. Las formas de representación sobre las historias y memorias de las poblaciones afrodescendientes en museos de Brasil se construyen a partir de una mirada exótica, esencialista, con el agravante de situarlas, siempre, en el ambiente rural. Esa mirada reductora no plantea las formas de organización colectiva, estrategias de resistencia ni las diversas prácticas educativas de las hermandades 
religiosas, organizaciones de artífices, de mujeres y hombres afrodescendientes. Esa mirada menguante construye una imagen de pasividad, aceptación de la esclavitud, privación de derechos que no discute el ultraje cultural del continente africano y sus culturas, ni los efectos de esas violencias que se prolongaron en las generaciones posteriores bajo distintas formas. Sobre el lugar de las mujeres negras, Cunha (2017) destaca que el silenciamiento es aún mayor y menciona las pocas iniciativas para darles visibilidad, como el Memorial Esperança Garcia, en la ciudad de Teresina, estado de Piauí, y el Memorial das Baianas Vendedoras de Acarajé e Mingau, en Salvador, Bahía.

Hay mucho que contar sobre la ambigüedad que traspasó la vida de mujeres esclavizadas y sus descendientes que han vivido y siguen viviendo en Brasil. Así como muchas mujeres negras dejaron de amamantar a sus hijos para dar su leche al hijo del señor durante la esclavitud colonial, hoy, en la persistencia de esa colonialidad en las escindidas ciudades brasileñas, muchas dejan a sus hijos en la periferia para trabajar en la casa de los señores pudientes sin saber si encontrarán sus hijos vivos al volver. Es el racismo cotidiano presente en el deliberado silenciamiento y exterminio de las poblaciones negras en Brasil, que emite señales precisas sobre dónde y cómo esa violencia verdaderamente se origina. El racismo cotidiano incorpora una cronología intemporal, pues no es solo la puesta en escena de un pasado colonial, sino también la negación de una realidad traumática. Fundamentada en el psicoanálisis, Kilomba (2019) menciona el proceso de negación en el cual el señor blanco contemporáneo niega su proyecto de colonización e impone al colonizado todo lo que se recusa a reconocer en sí mismo, lo que caracteriza el mecanismo de defensa del ego. Tal mecanismo permite a la blanquitud mirar para sí como moralmente ideal, decente, civilizada y majestuosamente generosa, sin preocuparse por las iniquidades que practica.

\section{Memorias americoafricanas}

Caracterizamos como memorias americoafricanas aquellas que emergen no solo en la memoria individual de las artistas seleccionadas en este artículo, sino también en la de muchas otras mujeres que se identifican con Americoáfrica como sistema etnogeográfico de referencia, en interacción con el contexto social. Son memorias mezcladas en lugares que despiertan recuerdos de vidas no siempre contadas, insinuadas en las miradas y medias palabras de secretos familiares, fragmentos de canciones, jerga y dichos populares. Es una producción artística marcada por la implicación personal, el impacto emocional, la inquietud sobre el pasado, la necesidad de recurrir a otras personas y archivos para narrar una historia que viene siendo negada. Trabajos que ponen en juego un pasado colectivo y traumático de muchas mujeres, que hacen ver la histórica herencia de racismo y sexismo ejercido sobre ellas.

Las denominamos memorias americoafricanas porque se inscriben en una historia que todavía no ha sido escrita, que hablan no solo a partir del olvido, sino también de los deliberados embustes y omisiones. Narrativas que desmitifican la patraña de una sociedad indivisa, ordenada, que explicitan la hipocresía de un cotidiano nada pacífico, la angustiosa opresión vivida por esas mujeres en relación con sus cuerpos, sus ancestralidades, sus herencias, recuerdos y lugares. Son producciones abiertas a los sentidos de sí y del otro, que contradicen la gran narrativa de la colonialidad, que reflejan y reflexionan sobre niveles de violencia extremos, en los que epistemicidios y genocidios son tan reales como la resistencia. Son trabajos que se hacen no solo para recordar, sino también para exponer la tirantez, la fricción irresuelta de esa punzante herida que no se cierra. Son narrativas inconclusas, provisionales, que afrontan los conflictos a partir del punto de vista de las mujeres que han tenido sus derechos negados. Creaciones que afrontan conflictos personales y colectivos, que navegan de un modo seguro entre el dolor y el placer, y se aventuran en otros significados de ficciones verdaderas que transforman sus experiencias y reestructuran subjetividades. 


\section{Parede da memória y Assentamento, de Rosana Paulino}

Rosana Paulino, ${ }^{5}$ nacida en la ciudad de São Paulo, Brasil, en 1967, es titulada en Grabado, con doctorado en Artes Visuales por la Universidad de São Paulo. En 2017, recibió el Premio de la Associação Brasileira de Cinema de Animação (ABCA) por su producción contemporánea. Como becaria de la Fundación Rockfeller participó de la residencia Bellagio Center Arts para artistas latinoamericanos en 2014. Tiene obra en los acervos del Museu de Arte Moderna (MAM) de São Paulo, Museu Afro Brasil, Pinacoteca do Estado de São Paulo y Art Museum University of New Mexico en los Estados Unidos. Muchas son sus exposiciones individuales y colectivas, las más recientes en el Museo Internacional de la Mujer (MIMA), en Lisboa, Portugal (2019); en la Clifford Art Gallery, Colgate University, Estados Unidos (2018); y en la Goodman Gallery de Cape Town, Sudáfrica (2017). Como artista se destaca por su producción vinculada a las cuestiones de género, raza y memoria. Sus trabajos se centran en las posiciones de las mujeres negras en la sociedad brasileña y en los tipos de violencia soportados por ellas en virtud de la esclavización. El trabajo de la artista contribuye para cuestionar la narrativa hegemónica sobre la esclavización, centrada en los instrumentos de tortura y la subordinación de las personas esclavizadas en el sistema colonial, para comprender cómo un pasado traumático tiene consecuencias sobre las generaciones subsiguientes.

La poética de Rosana Paulino hace uso de imágenes de distintos tipos de archivos, sean personales, familiares e institucionales.

Desde niña me gustaba curiosear en una caja de fotos que tenemos aquí en casa y llegó un momento que me dije: ¡Genial! Voy a trabajar con las fotos de la familia. Puedo saber quién soy, de dónde vinieron mis antepasados, mis padres, mi madre, mi abuela. No soy fotógrafa, tengo mucha dificultad con la fotografía pura, pero me gusta poner las fotografías en otras situaciones. De esta manera empecé Parede da memória. (Paulino, 2014)

Parede da memória es una instalación iniciada en 1994 y comprada por la Pinacoteca do Estado de São Paulo en 2015. En esa instalación, la artista ofrece una nueva versión del álbum de familia al apropiarse de once fotografías de su archivo personal, reproducidas en menor escala y multiplicadas sobre amuletos que se repiten como en un juego infantil. La artista logra una doble subversión en esa instalación, tanto por perturbar la estética del archivo como por alterar la práctica del amuleto, y nos ofrece su superficie y no su contenido como soporte para los retratos de sus familiares. Las prácticas religiosas de matriz africana asentadas en Brasil denominan el amuleto patuá y lo valoran por el contenido escondido en su interior. La propia artista ofrece sus impresiones sobre ese objeto de memoria: "Cuando yo era niña, tenía una gran curiosidad para saber lo que había oculto en el patuá. Yo no podía tocar el patuá, ni saber lo que contenía, pues solo quien lo hace puede saber lo que contiene" (Paulino, 2014) (figura 1).

Los álbumes de familia forman parte del legado transmitido a las generaciones posteriores y constituyen lo que Hirsch (2008) denomina fantasmagorías, en las que se mezclan imágenes y afectos pasados. Son objetos de culto y cuidado que se abren con emoción, como en un ritual a modo de "convocar a los espíritus" (Dubois 2006, 77). Lo que confiere valor a los álbumes de familia no son las cualidades plásticas y estéticas de las imágenes, sino los vestigios físicos de las personas que tienen relaciones particulares con aquellos que guardan esos signos.

Rosa Paulino reconstruye su ancestralidad y nos hace ver a sus antepasados otrora escondidos en su caja de fotografías, en una rectangular composición de 19 líneas y 78 columnas, formadas por los delicados amuletos. Una pequeña multiplicación de esas decenas nos lleva al resultado de 1482, año en que los portugueses llegaron al estuario del río Congo, en África, 


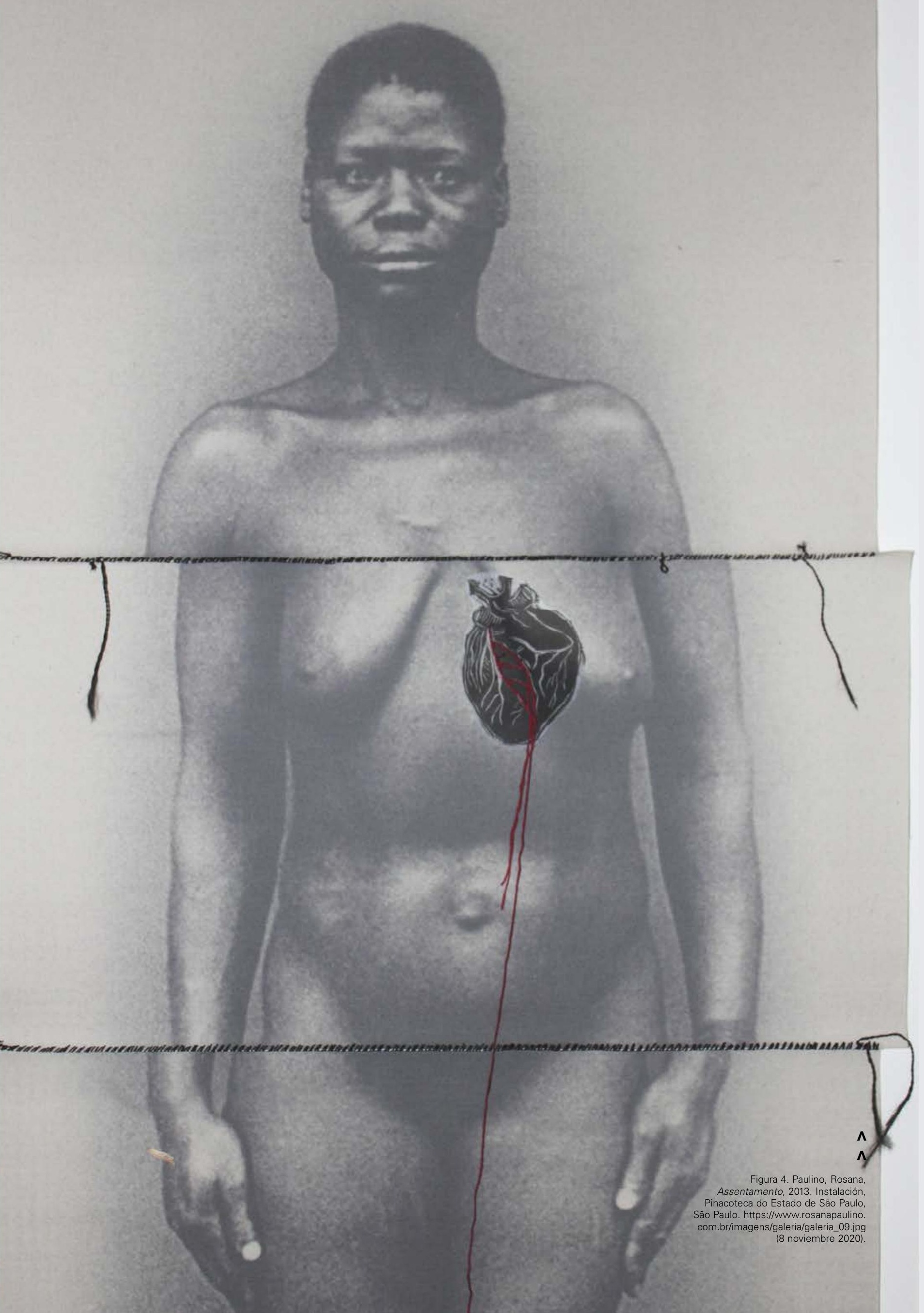


Figura 5. Motta, Aline, Escravos de Jó, 2016. Libro de artista. Sitio web de la artista. https:// payload.cargocollective. Escravos-de-Jo-3_4000.jpg (8 noviembre 2020).

$\Lambda$

$\Lambda$
En sus charlas, la artista pone de relieve el tiempo necesario para madurar su poética, lo que supuso tanto aspectos económicos para tornar sus proyectos factibles como la tranquilidad psíquica para poder tratar las cuestiones de su historia familiar (Motta 2017, 2019a). Fruto de un matrimonio interracial, la artista pudo experimentar las diferentes discriminaciones por colorismo, $^{7}$ de modo que fue considerada poco blanca para unos o poco negra para otros. Su familia mestiza, de madre negra y padre blanco, como muchas otras de Americoáfrica, sigue traspasada por las desiguales relaciones establecidas en el régimen esclavista, aún afligida por el racismo estructural y cotidiano que beneficia la ascendencia europea sobre la africana.

Los cuestionamientos sobre racismo van ganando cuerpo poco a poco en mi trabajo, en la medida en que sentía confianza y valor para tratar el tema con el rigor y la pesquisa que yo juzgo necesarios. Ha llevado su tiempo hasta que me sintiera madura y centrada para exponer aspectos tan profundos y difíciles que dicen respecto de mi propia historia y la de mi familia. (Motta, citado en Ferraz 2019)

Es en 2016 cuando su hacer artístico gana proyección con el libro de artista Escravos de Jó. El título del libro, que también se transformó en instalación posteriormente, remite a una cantiga tradicional brasileña. La melodía menciona el hacer zigzag de los esclavizados, tanto en los trabajos forzados como en las fugas no siempre llevadas a buen término, para el cual había que tener más paciencia que el santo Job para aguantar (figura 5).

El libro y la instalación juegan con las transparencias del papel vegetal y crean sobreposiciones entre imágenes y palabras de la cantiga tradicional, textos e imágenes de las notas cortas de los periódicos brasileños del siglo XIX que informan sobre esclavizados dados a la fuga (figura 6).

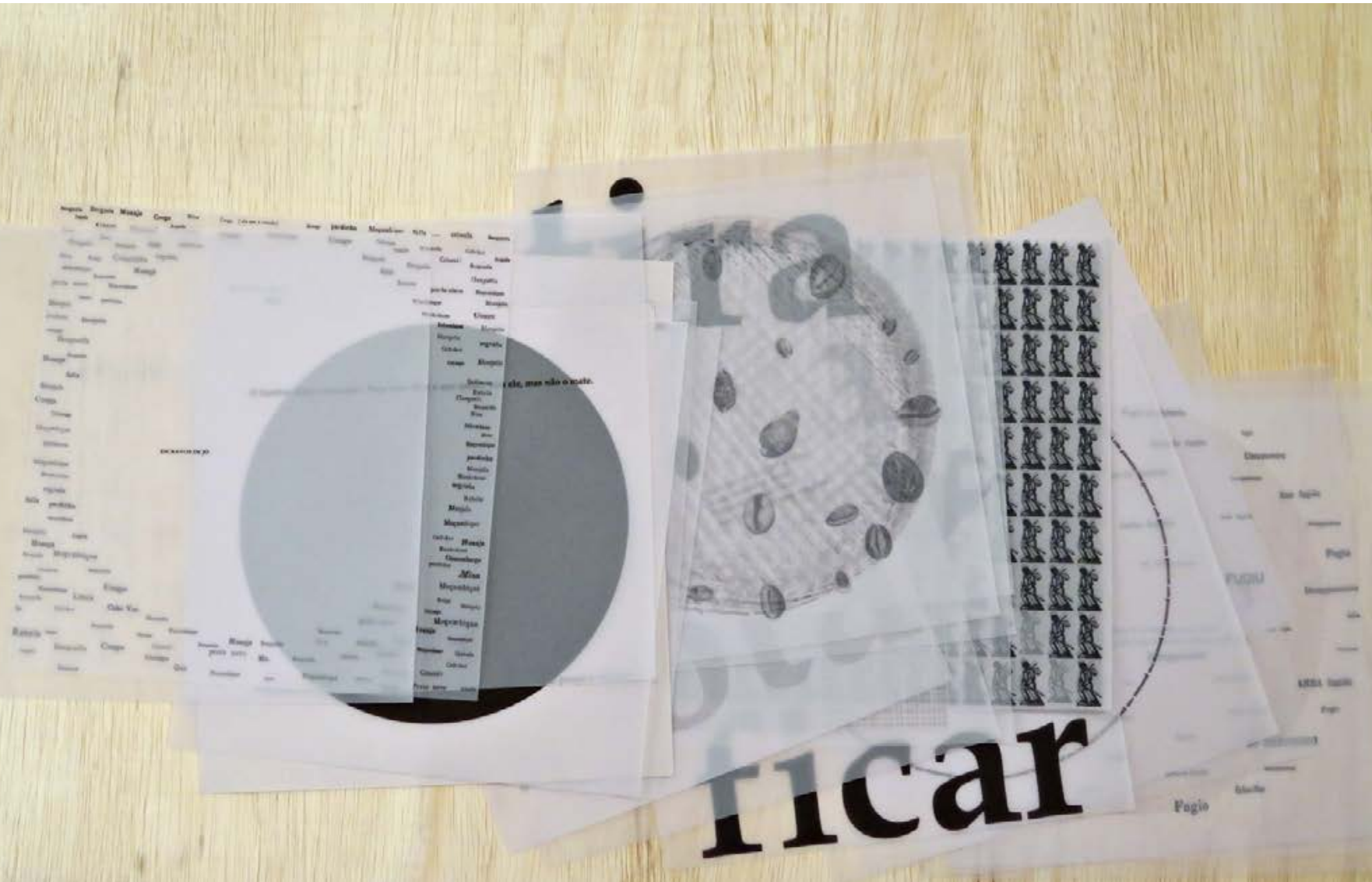




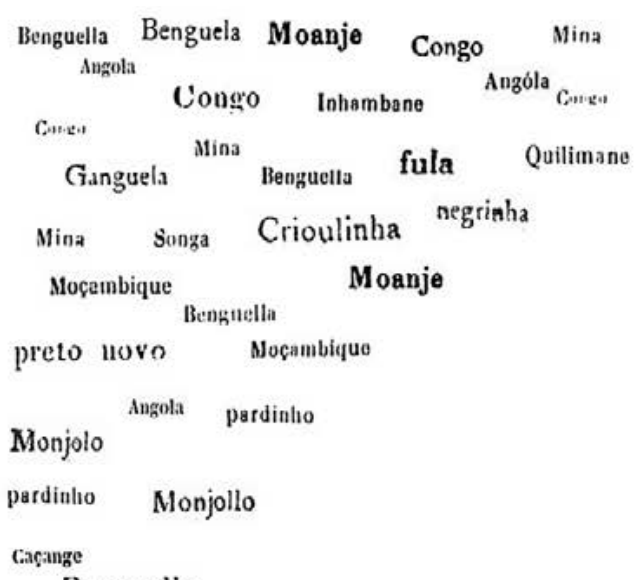

Benguella

$$
\begin{aligned}
& \text { Moanje } \\
& \text { Monguella } \\
& \text { fulla }
\end{aligned}
$$

Conga

$$
\text { Caçange }
$$

ESCRAVOS DE JÓ

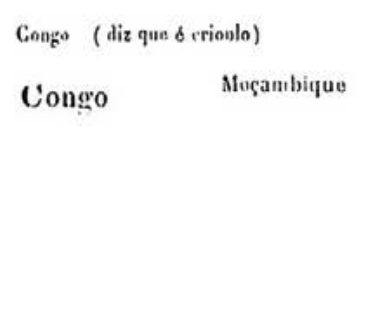

ronge

pardinbo Moçambique fulla ans crioula Benguella

Congo

Caçange Angóla Denquella Callabar Benguela Angóla ${ }^{2}$ Cabundi Benguella Angóla fulla Rebolo

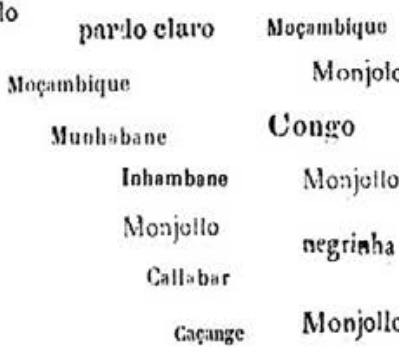
Quilimane Rebolo Ganguela Ilenguella Mina

Inhambane Mina Moçambique

pardinbo

Monjolo

Munhabane negrisha

Rebolo

Monjolo

negriaha

fulla pardinbo

Moȩambique

Monjollo Angóla

Moanje

Benguella Nuçambique

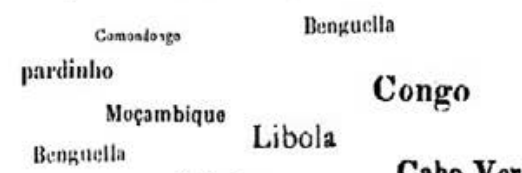

de Callabar Cabo Ver- Monjolo

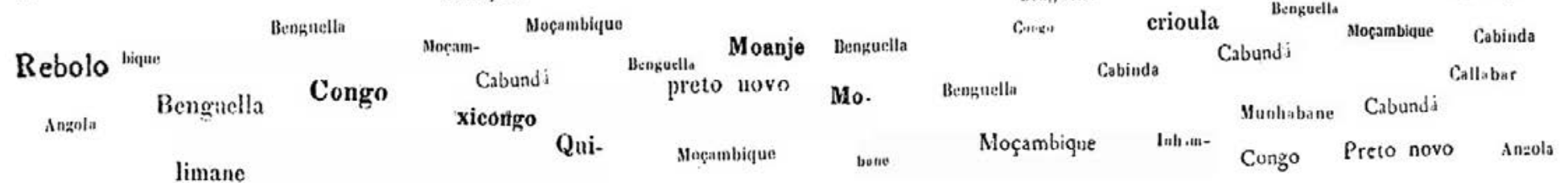

La artista destaca los adjetivos utilizados para describir a los fugitivos por las designaciones de los puertos de embarque, la ocupación en la plantación y las referencias del color de sus pieles en función del mestizaje. Algunas notificaciones de los periódicos también mencionan posibles relaciones de parentesco con esclavizados de otras plantaciones o direcciones de negros libres sospechosos de incitar rebeliones. Los cualitativos empleados en esas cortas notificaciones fueron transformándose en estigmas, marcas impuestas sobre las pieles de los cuerpos esclavizados, condenas infames, signos de inmundicia, vileza, desprecio e insignificancia.

Así como los esclavizados eran tratados como objetos que pasaban por la mano de diferentes señores, las hojas del libro y la instalación pasan por nuestras manos, rompen con el privilegio de la mirada y descubren las capas sutiles de esa historia entre los dedos. Nos movemos entre la blancura del papel y el negro de las formas

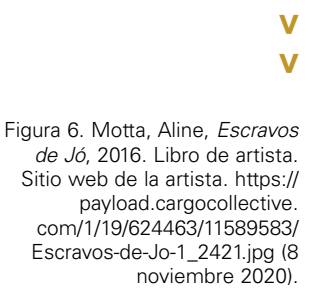

gura 6. Motta, Aline, Escravos de Jo, 2016. Libro de artista.

payload.cargocollective. com/1/19/624463/11589583/ noviembre 2020). 


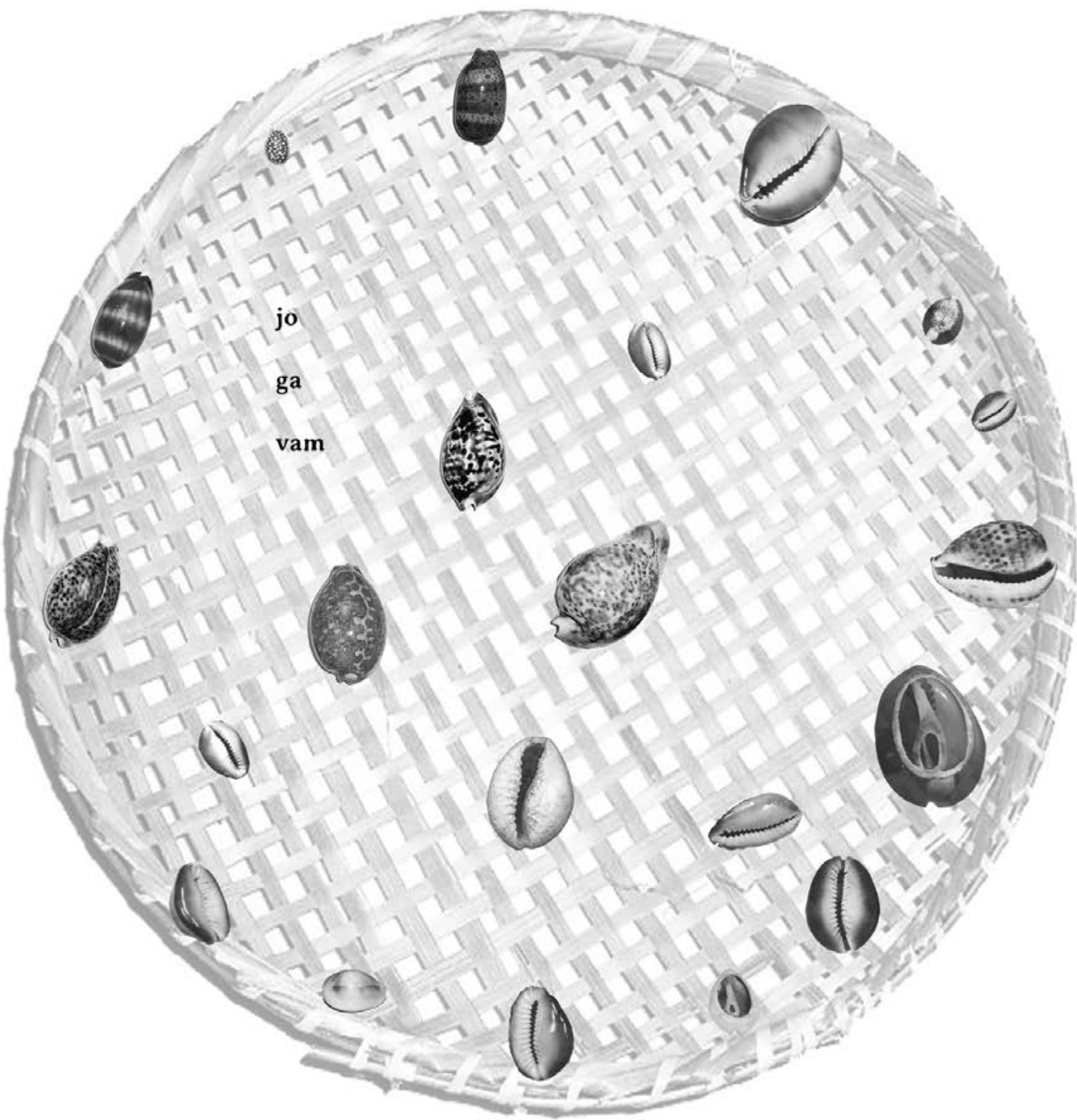

Figura 7. Motta, Aline, Escravos de Jó, 2016 Libro de artista. Sitio web de la artista. https:/ payload.cargocollective. com/1/19/624463/11589583/ Escravos-de-jo-5_2421.jpg (8 noviembre 2020). impresas en las 26 láminas, entre los entrantes y salientes de una ruta que no nos lleva al paciente santo Job, sino a una alteración lingüística de "nzo", que en lengua kikongo ${ }^{8}$ quiere decir casa. Puede ser que la canción haga referencia al juego que las esclavizadas que servían en la casa grande de los señores practicaban. En una de las páginas del libro llegamos al "juego de buzios" (figura 7), arte adivinatoria practicada con conchas y caracolas del mar, tradicional de las religiones africanas y de la diáspora africana asentada en Americoáfrica.

Filha natural es un proyecto artístico para el cual fluye toda la investigación etnográfica y genealógica iniciada en sus creaciones anteriores: Oynbó (2017) en el que reconoce su identificación americoafricana; Pontes sobre o abismo (2017), la genealogía iniciada a partir del secreto revelado por su abuela Doralice (1911-2012); Se o mar tivesse varandas (2017), a partir del estribillo de una canción tradicional portuguesa; (Outros) Fundamentos (2017-2019), la travesía entre las ciudades de Cachoeira, en el estado de Bahía, Río de Janeiro, y Lagos, en Nigeria.

Toda la investigación empezó de una manera inesperada, cuando mi abuela reveló su gran secreto. A partir de las pocas pistas que mi abuela ofreció poco antes de morir, empecé mi búsqueda de los archivos. Ha sido sorprendente encontrar tanta documentación, especialmente para una familia negra, pues, equivocadamente, creíamos que 
los archivos sobre la esclavitud habían sido quemados o eran inexistentes. He encontrado varios documentos. Pienso que es necesario investigar otros puntos de vista en esos documentos. En general, los estudios historiográficos brasileños focalizan la élite esclavista, no las mujeres y hombres esclavizados. (Motta, citado en Gonzatto 2020)

La expresión hijo/a natural hace referencia a un término jurídico para indicar a las personas nacidas de madre y padre solteros que podrían casarse al tiempo de tenerlo. Esa expresión se utilizó en Brasil hasta 1988. En general, en ese tipo de registro, solo constaba el nombre de la madre del nacido, a no ser que el padre lo reconociera, hecho nada frecuente entre los señores de esclavizados que tenían sus bienes aumentados con esa filiación bastarda. Motta trata de esa condición en las vidas de su abuela, bisabuela y tatarabuela en sus producciones artísticas. En el caso de su abuela Doralice, esta reveló el gran secreto de su vida, el nombre de su padre, poco antes de fallecer. En sus investigaciones por los diversos archivos institucionales, la artista averiguó que el padre de su abuela era el hijo del señor de la casa donde su bisabuela, Mariana, trabajara como sirvienta. La artista supone que Francisca, su tatarabuela, también sería hija natural de algún hombre de la familia Pereira de Almeida, propietaria de la Fazenda Ubá, ${ }^{9}$ de modo que era Francisca uno de sus bienes. Esa propiedad se conserva hasta hoy y hace parte de una ruta turística que preserva las construcciones coloniales denominadas casa grande, el edificio donde vivían los señores y vigilaban a los esclavizados desde los anchos cobertizos de la vivienda. Los inicios de esa propiedad remontan al barón de Ubá, João Rodrigues Pereira de Almeida (Lisboa, 1781-Río de Janeiro, 1830), un hombre dedicado al lucrativo negocio del tráfico de esclavizados.

Motta realiza Filha natural, en ese local de memoria, la Fazenda Ubá. Para ese conjunto de producciones, formada por instalación fotográfica, performance y video, la artista se apropia y cita dos fotografías estereoscópicas ${ }^{10}$ tomadas por el fotógrafo alemán Revert Henrique Klumb (1830-1886) en el cobertizo de esa propiedad en 1860 (figura 8).
Figura 8. Motta, Aline, Filha natural, 2019-2019. Instalación fotográfica. Sitio web de la artista. https://payload.cargocollective. https://payload.cargocollective. com/1/19/624463/13688328/ web_1701.jpg (8 noviembre 2020).

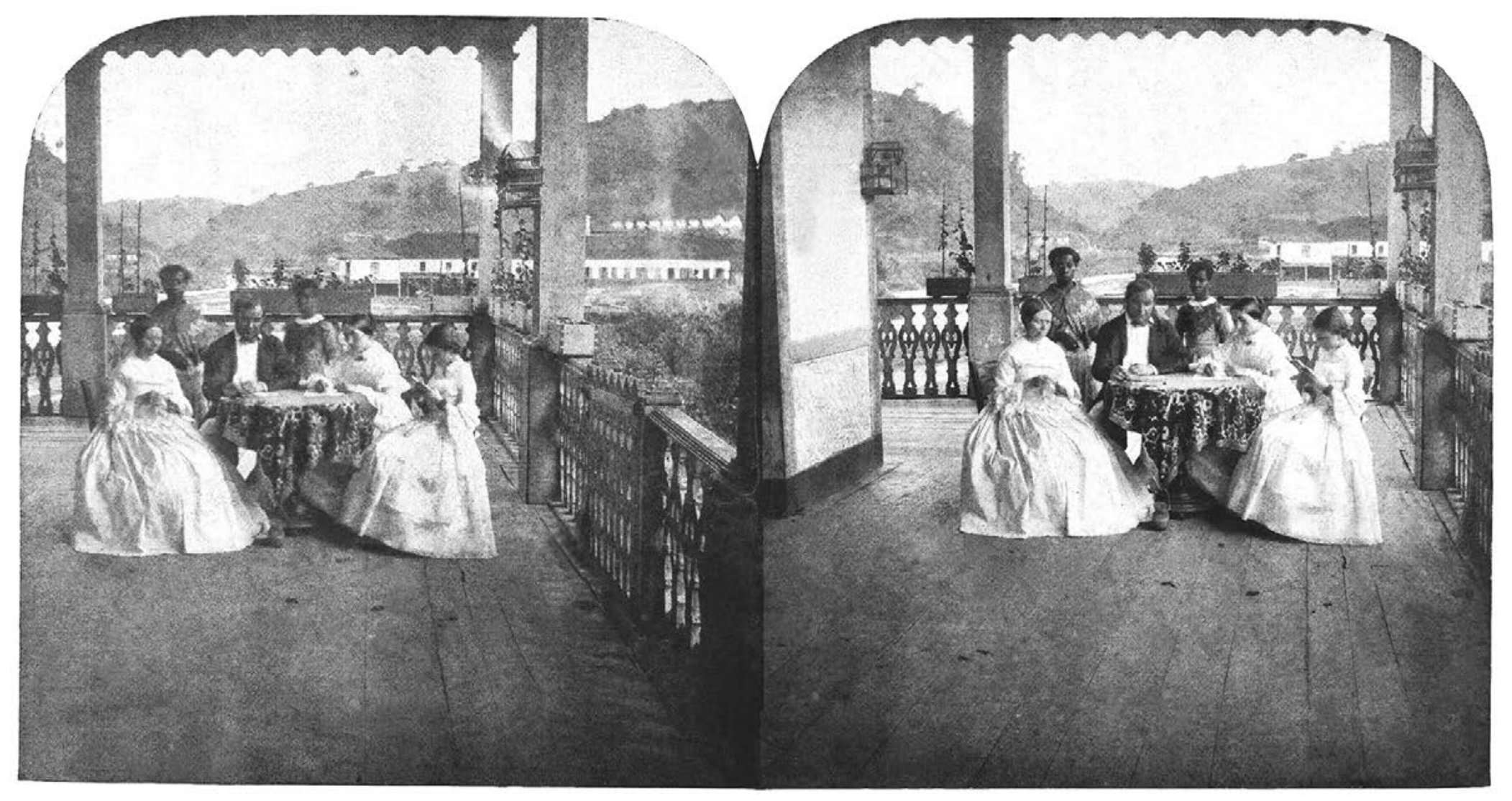




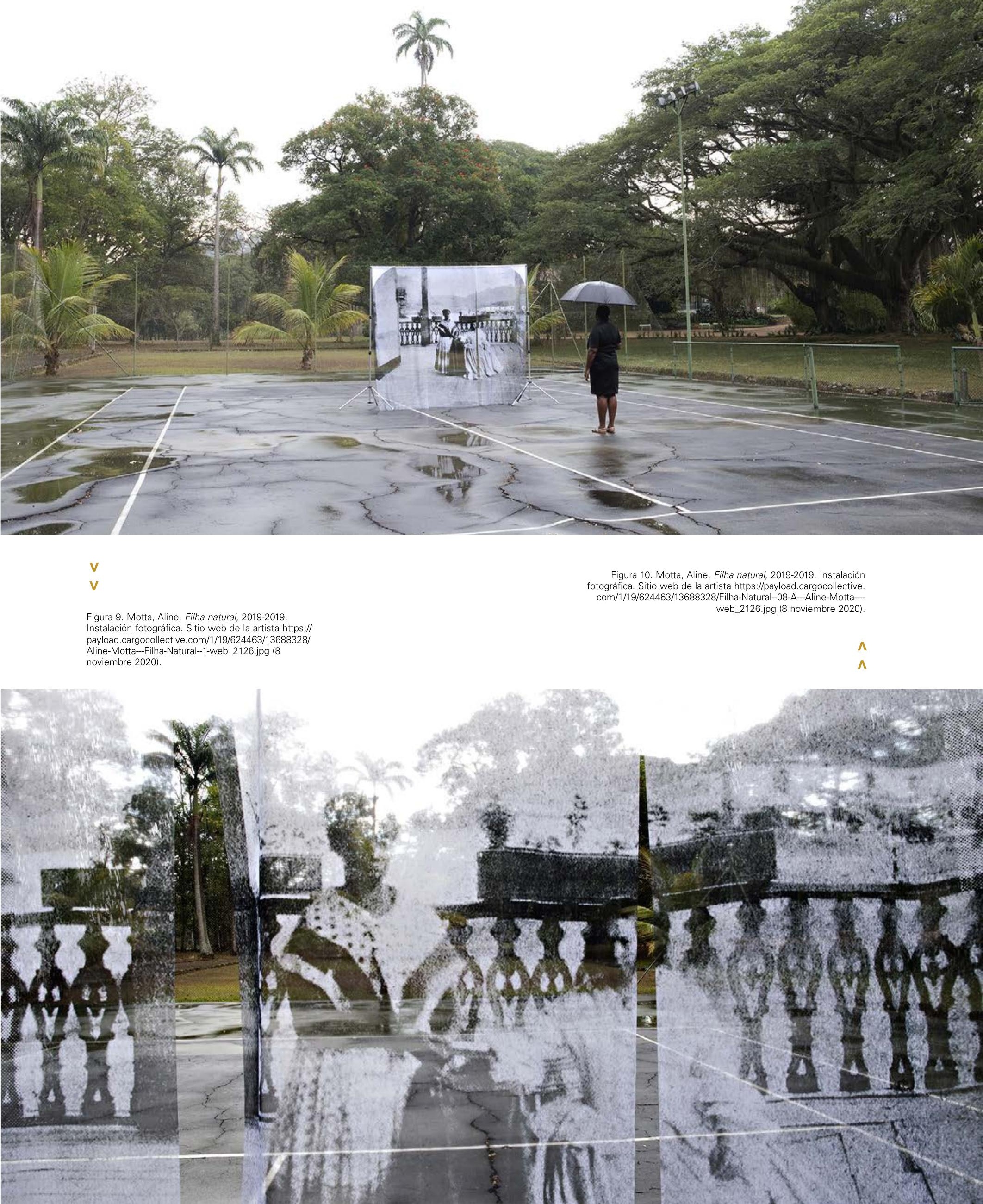


En el video, la artista narra la vida de las mujeres esclavizadas fotografiadas en el siglo XIX, a partir de los datos encontrados en los archivos del periódico Diário Fluminense, del Instituto do Patrimônio Histórico e Artístico Nacional (IPHAN) y los registros civiles de la región. También de fragmentos de libros de viajeros franceses que visitaron la propiedad en el siglo XIX, como el botánico Auguste de Saint-Hilaire (1779-1853), autor de Viagem pelas províncias do Rio de Janeiro e Minas Gerais (Saint-Hilaire, 1938) y Brasil pintoresco, del periodista Charles Ribeyrolles (1812-1860) (figura 9).

La líder comunitaria de la región, Claudia Mamede es la figura central de la performance. La artista intercambió fotografías familiares con la líder comunitaria y ambas encontraron muchas semejanzas físicas entre sus antepasadas. La diáspora africana gestó la noción de familia ampliada y, posiblemente, esas mujeres tengan ancestros comunes, aparte de las traumáticas experiencias como mujeres americoafricanas. De esa manera, la artista rellena los huecos del pasado con mujeres del presente para reflexionar sobre el trauma transgeneracional (figura 10).

Las sobreposiciones de diferentes materiales y las transparencias, ya presentes en la producción de Escravos de Jó, también son visibles en Filha natural. Motta experimenta la fotografía y el video en soportes poco comunes, como agua corriente, vegetación, espejos y ruinas. Sobrepone imágenes y temporalidades que conducen a una narrativa que articula lo real, lo simbólico y lo imaginario, y recrea los sentidos de la realidad. Paradojas de fabulaciones verdaderas que hablan de vidas contemporáneas (figura 11).

Al proyectar las cartografías poéticas que construye en distintas pantallas al mismo tiempo, Motta crea la posibilidad de una narrativa no lineal en los espacios de memoria que vivieron

Figura 11. Motta, Aline Filha natural, 2019-2019. Instalación fotográfica. Sitio web de la artista. https:// payload.cargocollective.
rom/1/19/624463/13688328/ IMG_3692x_4000.jpg (8
IM_ noviembre 2020).
} 
Quizá la producción artística pueda provocar otras conexiones en los espectadores, pueda ofrecer otros caminos que lleven a pensar sobre los traumas personales, familiares y colectivos. En Brasil, todavía, las artes visuales son un campo muy restricto y elitista. Por eso, tengo muchas dudas en relación con los efectos que mi trabajo pueda causar. (Motta, citado en Gonzatto 2020)

Consideramos que la producción artística de Motta causa una ruptura de la narrativa ancorada en la escenificación colonial. La artista realiza la urgente tarea de visibilizar los archivos y la iconografía del siglo XIX, para conectar la discusión sobre traumas personales, familiares y colectivos, deber que el refractario sistema del arte de Brasil hace parca y lentamente.

\section{Consideraciones transitorias}

Las narrativas de Rosana Paulino y Aline Motta están doblemente marcadas por situaciones no vividas del pasado, el trauma transgeneracional y un cruel presente en el que los excesos de la escenificación colonial se preservan bajo el genocidio que se sigue practicando contra mujeres y hombres negros. Sus narrativas despliegan recuerdos traumáticos no como víctimas, sino que visibilizan, sin rodeos, las prácticas de abuso y la resistencia a ellas. Es un trabajo alimentado por cuestiones estéticas y éticas que nos hacen ver los diversos actores implicados en las atrocidades de hoy y ayer.

Consideramos que la producción artística presentada se caracteriza como trabajos del arte de la memoria por la implicación personal de sus productoras y por el impacto emocional que supone la narración sobre la vida, sus inquietudes sobre el pasado, las búsquedas de huellas, la necesidad de recurrir al testimonio de otras personas y archivos para construir la propia historia. Son trabajos que expresan los conflictos intrapsíquicos que sobrevienen en relación con el pasado traumático, reprimidos por una historia única que no incluye otras miradas. La represión ejercida por esa historia única obstaculiza el flujo vital de las memorias excluidas. Al recuperar imágenes e historias de vida del pasado, por medio de sus procesos creativos, las artistas buscan movilizar la capacidad de dar sentido y estructurar lo interno, narrar de otro modo, crear otras versiones de los traumas colectivos que no forman parte del relato oficial. Construyen nuevos archivos como un trabajo de duelo, como un proceso de reestructuración personal y colectiva.

Recopilan fotografías, documentos y objetos que reconstruyen historias olvidadas en el cruce subjetividad y colectividad, entre la historia personal y el relato público. Nos ofrecen una posibilidad de replantear el sentido de identidad personal y colectiva. Constatan y contestan las heridas y las perforaciones que los acontecimientos han producido aproximando documentos diferentes, intercalando documentación pública y relatos individuales, familiares, mezclando la historia subjetiva y colectiva. Crean archivos abiertos para discutir el presente e iluminan lo que no estaba visible.

Son memorias americoafricanas porque se gestaron en la resistencia y creatividad contra la opresión, la humillación y la deshumanización. Experiencias comunes de mujeres que se identifican con Americoáfrica, como sistema etnogeográfico de referencia. Son memorias americoafricanas porque no solo hablan de los cuerpos femeninos y los lugares ocupados por esos cuerpos en la escenificación colonial que perdura en la contemporaneidad, sino que se insurgen contra la historia única y proponen una revisión de la historiografía del país y del arte producido a partir de esos lugares. 
1. No debe confundirse con el gentilicio estadounidense.

2. Blanquitud como un lugar estructural desde el cual la identidad blanca piensa las demás y a sí misma, a partir de una posición de poder desde la cual se atribuye al otro aquello que no se atribuye a sí mismo (Cardoso 2010).

3. Usamos la palabra esclavizada y no esclava por describir un proceso político activo de deshumanización. Esclava describe el estado de deshumanización como identidad natural de las personas que fueron esclavizadas (Kilomba 2019).

4. En el culto de matriz africana, denominado de candomblé en Brasil, la expresión "hacer la cabeza" significa ser preparado para que el Orixá (deidad) pase a habitar el Ori, la cabeza del nuevo adepto (Carmo 1987).

5. El sitio web de la artista Rosana Paulino es http://www.rosanapaulino.com.br/.

6. El sitio web de la artista Aline Motta es http://alinemotta.com/.

7. Concepto de la escritora y activista feminista estadounidense Alice Walker, que hace referencia a un tipo de discriminación que beneficia a las personas de piel más clara de una misma raza. La autora utilizó ese concepto por primera vez en el ensayo "If the Present Looks Like the Past, What Does the Future Look Like?", publicado en el libro In Search of Our Mothers' Gardens: Womanist Prose, de 1982.

8. Lengua africana hablada por el pueblo bakongo, originario de las regiones del actual norte de Angola y el denominado bajo Congo, parte de las actuales República del Congo y República Democrática del Congo.

9. Esa propiedad está localizada en la actual ciudad de Vassouras, en el estado de Río de Janeiro.

10. La técnica estereoscópica produce la ilusión de tres dimensiones a partir de un par de imágenes en dos dimensiones. El observador tiene la percepción de profundidad a partir de dos imágenes, que representan el mismo objeto a partir de distintas perspectivas en una desviación próxima a la forma natural que cada ojo recibe en la visión binocular. 
[REFERENCIAS]

Adichie, Chimamanda Ngozi. 2019. 0 perigo de uma história única. São Paulo: Cia das Letras.

Arfuch, Leonor. 2000. "Arte, memoria y archivo". Revista de Cultura 68: 34-37.

Arfuch, Leonor. 2014. "(Auto)biografía, memoria e historia". Clepsidra: Revista Interdisciplinaria de Estudios sobre Memoria 1: 68-81.

Cao, Marian López Fernández. 2018. "Dar forma al dolor”. En Arte, memoria y trauma: Aletheia, dar forma al dolor, editado por Marian López Fernández Cao, 13-35. Madrid: Fundamentos.

Cardoso, Lourenço. 2010. "Branquitude acrítica e crítica: A supremacia racial e o branco antirracista". Revista Latinoamericana de Ciencias Sociales Niñez Juventud, 8 (1): 607-630.

Carmo, João. 1987. O que é Candomblé. São Paulo: Brasiliense.

Chauí, Marilena. 2013. "Representação política e enfrentamento ao racismo". Geledés Instituto da Mulher Negra, 9 de mayo de 2013. Consultado: 3 de noviembre de 2020. https://www.geledes.org.br/representacaopolitica-e-enfrentamento-ao-racismo-prof-marilena-chaui/.

Cunha, Marcelo Nascimento Bernardo da. 2017. “Museus, memorias e culturas afro-brasileiras". Revista do Centro de Pesquisa e Formação 5: 78-88.

Dubois, Philippe. 2006. 0 ato fotográfico. Campinas: Papirus.

Evaristo, Conceição. 2008. Poemas da recordação e outros movimentos. Belo Horizonte: Nandyala.

Ferraz, Marcos Grinspum. 2019. "Aline Motta e o mergulho pessoal na memória coletiva". ARTE!Brasileiro, 20 de noviembre de 2019. Consultado: 3 de noviembre de 2020. https://artebrasileiros.com.br/arte/premio/alinemotta-e-0-mergulho-pessoal-na-memoria-coletiva/.

Freyre, Gilberto. 2003. Casa-grande \& senzala: Formação da família brasileira sob o regime da economia patriarcal. São Paulo: Global.

Gómez Moreno, Pedro Pablo. 2015. Estéticas fronterizas: Diferencia colonial y opción estética decolonial. Bogotá: Universidad Distrital Francisco José de Caldas.

Gonzalez, Lélia. 1979. “Cultura, etnicidade e trabalho: Efeitos lingüísticos e políticos da exploração da mulher". Ponencia presentada en el $8^{\circ}$ nacional da Latin American Studies Association, Pittsburg.

Gonzalez, Lélia. 1981. “Mulher negra, essa quilombola". Folhetim 4: 4.

Gonzalez, Lélia. 1982. “0 movimento negro na última década". En Lugar de negro, Lélia Gonzalez y Carlos Alfredo Hasenbalg, 9-66. Río de Janeiro: Marco Zero.

Gonzalez, Lélia. 1984. "Racismo e sexismo na cultura brasileira". Revista Ciências Sociais Hoje 2: 223-244.

Gonzalez, Lélia. 1988a. "Cidadania de segunda classe". Río de Janeiro.

Gonzalez, Lélia. 1988b. "A categoria político-cultural de amefricanidade". Tempo Brasileiro 92: 69-82.

Gonzalez, Lélia. 1994. "Lélia fala de Lélia”. Estudos Feministas 2: 383-386.
Gonzalez, Lélia. 2011. "Por um feminismo afro-latino-americano". Caderno de Formação Política do Círculo Palmario 1: 12-20.

Gonzatto, Camila. 2020. "Não há cicatrização sem políticas de reparação". Consultado: 3 de noviembre de 2020. https://www. goethe.de/ins/br/pt/kul/sup/b20/21779451.html.

Halbwachs, Maurice. 1990. A memória coletiva. São Paulo: Vértice.

Hall, Stuart. 2003. Da diáspora: Identidades e mediações culturais. Belo Horizonte: Universidade Federal de Minas Gerais.

Hirsch, Marianne. 2008. "The Generation of Postmemory". Poetics Today 29 (1): 103-128.

Kilomba, Grada. 2019. Memórias da plantação: Episódios de racismo cotidiano. São Paulo: Cobogó.

Le Goff, Jacques. 1990. História e memória. Campinas: Universidade Estadual de Campinas.

Luz, Narcimária Correia do Patrocínio. 2006. “História e cultura afrobrasileira e africana". Boletim TVe 20: 12-20.

Motta, Aline, Escravos de Jó, 2016. Libro de artista. Sitio web la artista. https://payload.cargocollective.com/1/19/624463/11589583/ Escravos-de-Jo-3_4000.jpg (8 noviembre 2020).

Motta, Aline. 2017. "Conversa na 14 ${ }^{a}$ Residência Artística do Red Bull Station". Consultado: 3 de noviembre de 2020. https://www. youtube.com/watch?v=7YM6oZPxGR8.

Motta, Aline. 2019. "Conversa no Festival ZUM". Consultado: 3 de noviembre de 2020. https://www.youtube.com/watch?v=VfiYeLClit0.

Nicholson, Chris. 2018. “No más fantasmas: La memoria traumática en la vida y la obra de Robert Graves". En Arte, memoria y trauma: Aletheia, dar forma al dolor, editado por Marian López Fernández Cao, 71-78. Madrid: Fundamentos.

Nora, Pierre. 1993. “Entre memória e história: A problemática dos lugares". Projeto História 10: 7-28.

Paulino, Rosana. 1997. Catálogo Panorama 97. São Paulo: Museu de Arte Moderna.

Paulino, Rosana, Assentamento, 2013. Instalación, Pinacoteca do Estado de São Paulo, São Paulo. https://www.rosanapaulino. com.br/imagens/galeria/galeria_09.jpg (8 noviembre 2020).

Paulino, Rosana. 2014. "Processo criativo - Rosana Paulino". Consultado: 3 de noviembre de 2020. https://vimeo.com/111885499.

Quijano, Aníbal. 2005. “Colonialidade do poder, eurocentrismo e América Latina". En A colonialidade do saber: Eurocentrismo e ciências sociais. Perspectivas latinoamericanas, editado por Edgardo Lander, 43-66. Buenos Aires: Consejo Latinoamericano de Ciencias Sociales.

Romero, Julio. 2018. "Archivos abiertos: La imagen, el objeto y el montaje en prácticas artística y de intervención social sobre la memoria y el trauma". En Arte, memoria y trauma: Aletheia, dar forma al dolor, editado por Marian López Fernández Cao, 139-166. Madrid: Fundamentos. 
Ruido, Maria. 2018. "Notas sobre Plan Rosebud: Sobre imágenes, lugares y políticas de memoria (2006-2008)". En Arte, memoria y trauma: Aletheia, dar forma al dolor, editado por Marian López Fernández Cao, 177- 192. Madrid: Fundamentos.

Sant-Hilaire, Auguste de. 1938. Viagem pelas províncias do Rio de Janeiro e Minas Gerais. São Paulo: Ed. Nacional.

Theodoro, Mário. 2008. As políticas públicas e a desigualdade racial no Brasil 120 anos após a abolição. Brasília: Ipea.

Todorov, Tzvetan. 2000. Los abusos de la memoria. Barcelona: Paidós. 